\title{
Calcareous Nannofossil Biostratigraphy of Cenozoic Sediments from the Millhaven Core, Screven County, Georgia
}

By Laurel M. Bybell

\section{U.S. GEOLOGICAL SURVEY PROFESSIONAL PAPER 1603-F}




\section{CONTENTS}

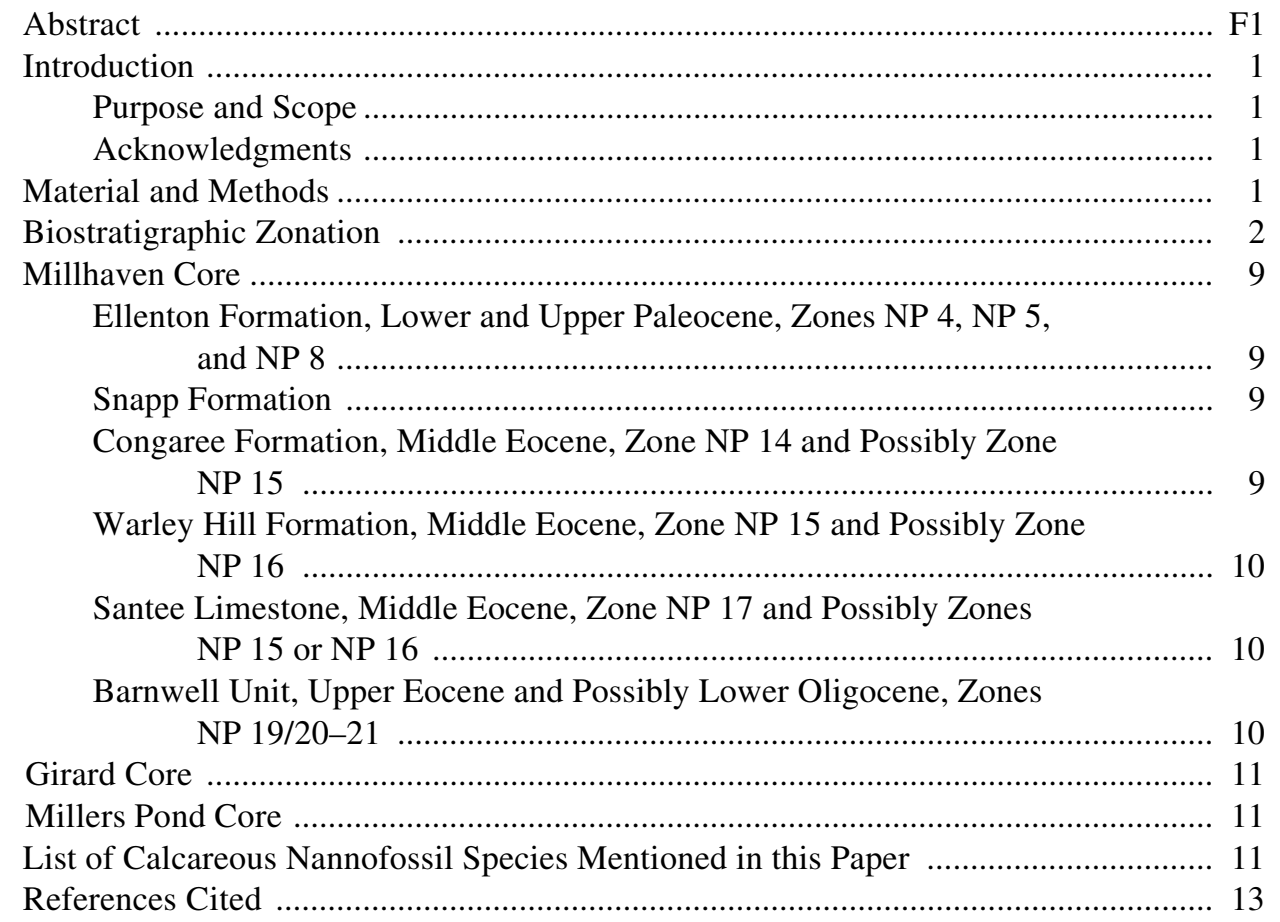

\section{PLATE \\ [Plate follows References Cited]}

1. Coccolithus, Discoaster, Reticulofenestra, Transversopontis, Helicosphaera, Blackites, Placozygus, Ericsonia, and Toweius.

\section{FIGURES}

1. Index map showing the location of the Millhaven, Girard, and Millers Pond test holes in Georgia and additional test holes in South Carolina

2. Chart showing calcareous nannofossil biostratigraphic zonation of Cenozoic intervals in the Millhaven core from Georgia

3. Calcareous nannofossil occurrence chart for Cenozoic deposits in the Millhaven core from Georgia 


\title{
Calcareous Nannofossil Biostratigraphy of Cenozoic Sediments from the Millhaven Core, Screven County, Georgia
}

\author{
By Laurel M. Bybell
}

\begin{abstract}
Calcareous nannofossils were examined from the Cenozoic portion of the Millhaven core that was drilled by the U.S. Geological Survey in Screven County, Georgia. Calcareous nannofossil Zones NP 4, NP 5, and NP 8 are present in the Paleocene Ellenton Formation; calcareous nannofossils were not examined from the overlying noncalcareous Snapp Formation; Zone NP 14 is present in the overlying middle Eocene Congaree Formation; Zone NP 15 occurs in the Warley Hill Formation; Zone NP 17 occurs in the upper middle Eocene Santee Limestone; and Zone 19/ 20 and probably Zone 21 occur in the upper Eocene and possibly lower Oligocene Barnwell unit. A few samples were examined from the Ellenton Formation in the core from the nearby Girard test hole and the Santee Limestone in the Millers Pond core. These samples could add no more precise information concerning the age of these two formations.
\end{abstract}

\section{INTRODUCTION}

\section{PURPOSE AND SCOPE}

In this study, calcareous nannofossils were examined from 68 samples from the Cenozoic portion of the Millhaven core in order to establish a biostratigraphic framework that could be used to understand better the groundwater flow in the aquifers in the region near the Savannah River Site. I anticipated that calcareous nannofossils would not be useful in dating the more updip Girard and Millers Pond test holes, but I examined a few select samples in order to test this hypothesis. Falls and Prowell (this volume, chap. A) describe the lithology and physical stratigraphy of the Cretaceous and Cenozoic sediments recovered in the cores.

\section{ACKNOWLEDGMENTS}

Donald Queen, Eugene Cobbs, and Eugene Cobbs III, of the U.S. Geological Survey (USGS), drilled the Millhaven corehole, and I thank them for their diligent efforts in obtaining good core recovery. I thank Jean M. Self-Trail (USGS) and Amanda Chapman (USGS) for their preparation of the calcareous nannofossil samples and their excellent illustrations. I also thank Jean M. Self-Trail and Raymond A. Christopher (Clemson University) for their thoughtful reviews of the manuscript.

\section{MATERIAL AND METHODS}

The Millhaven test hole (33X048) was drilled in Screven County, Ga., in late 1991 and early 1992 as part of a cooperative effort among the U.S. Geological Survey, the U.S. Department of Energy, and the Georgia Geologic Survey of the Georgia Department of Natural Resources. The test hole is located at lat $32^{\circ} 53^{\prime} 25^{\prime \prime} \mathrm{N}$. and long $81^{\circ} 35^{\prime} 43^{\prime \prime}$ W. (fig. 1). The drill site is located at an altitude of $110 \mathrm{ft}$, and the test hole was drilled to a depth of 1,452 ft. The hole was continuously cored, and the cores are temporarily stored at the U.S. Geological Survey in Reston, Va.

Sixty-eight samples between the depths of 639.6 and $59.8 \mathrm{ft}$ in the Millhaven core were examined for their calcareous nannofossil content (fig. 2). Two samples were examined from the Girard core (32Y020), which was drilled by the U.S. Geological Survey in 1992 in southern Burke County, Ga., at the lookout tower on Griffins Landing Road, 2 miles north of the town of Girard at lat $33^{\circ} 03^{\prime} 54^{\prime \prime} \mathrm{N}$. and long $81^{\circ} 43^{\prime} 13^{\prime \prime}$ W. (fig. 1). Three samples were examined 


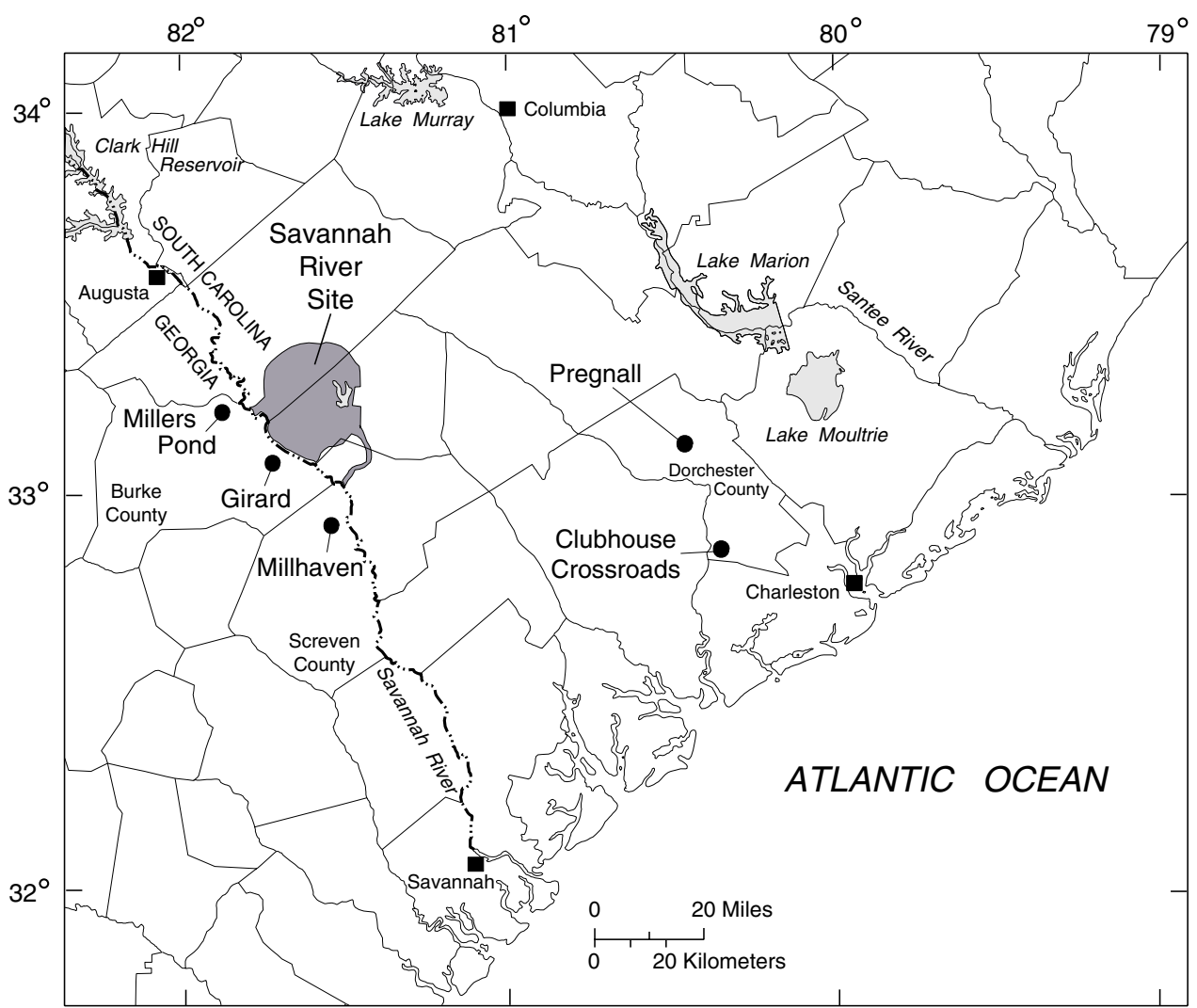

Figure 1. Location of the Millhaven, Girard, and Millers Pond test holes in Georgia and additional test holes in South Carolina.

from the Millers Pond core (GGS-3758, Burke 2), which was drilled by the Georgia Geologic Survey in 1991 in northern Burke County, Ga., 2 miles west of the Savannah River and 16 miles south of Augusta at lat $33^{\circ} 13^{\prime} 48^{\prime \prime}$ N. and long $81^{\circ} 52^{\prime} 44^{\prime \prime}$ W. (fig. 1). Comparisons are made with calcareous nannofossil data obtained from the Clubhouse Crossroads core No. 1 (Hazel and others, 1977) and the Pregnall core (Edwards and others, 1997), both located in Dorchester County, S.C.

Calcareous nannofossil samples were extracted from the central portion of core-segment surfaces (freshly broken where possible) at approximately 2 - to 10 -ft intervals. The samples were dried in a convection oven to remove residual water, and the resultant sediment was placed in vials for long-term storage in the author's laboratory at the U.S. Geological Survey in Reston, Va. A timed settling procedure was used to obtain the optimum sediment-size fraction. For this procedure, a small amount of sample was placed in a beaker, stirred, and settled through $2 \mathrm{~cm}$ of water. The first settling time was 1 minute to remove the coarse material, and the second settling time was 10 minutes to remove the fine clay fraction. Smear slides then were prepared from the remaining material. Cover slips were attached to the slides using Norland Optical Adhesive (NOA-65), a clear adhesive that bonds glass to glass and cures when exposed to ultraviolet radiation.

Initially, all samples were examined by using a Zeiss Photomicroscope III. A few samples, which were thought to have the best preservation and the highest abundances of calcareous nannofossils, were scanned by using a JEOL 35 scanning electron microscope (SEM). Photomicrographs of several of the best preserved specimens are presented on plate 1.

\section{BIOSTRATIGRAPHIC ZONATION}

In this study, the biostratigraphic zonation of the Cenozoic strata is based primarily on the calcareous nannofossil zonation of Martini (1971) and secondarily on the zonation of Bukry $(1973,1978)$ and Okada and Bukry (1980). The calcareous nannofossil assemblages usually were sufficient in numbers of specimens, diversity of taxa, and preservational state in the Millhaven strata to allow placement of most samples within one specific calcareous nannofossil zone (fig. 3).

Text continues on p. F8. 


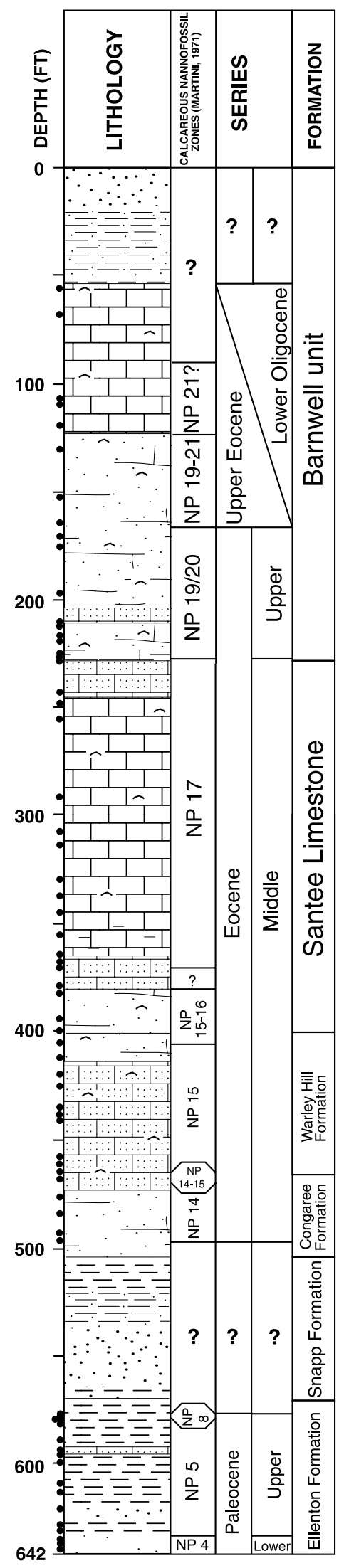

\section{EXPLANATION}

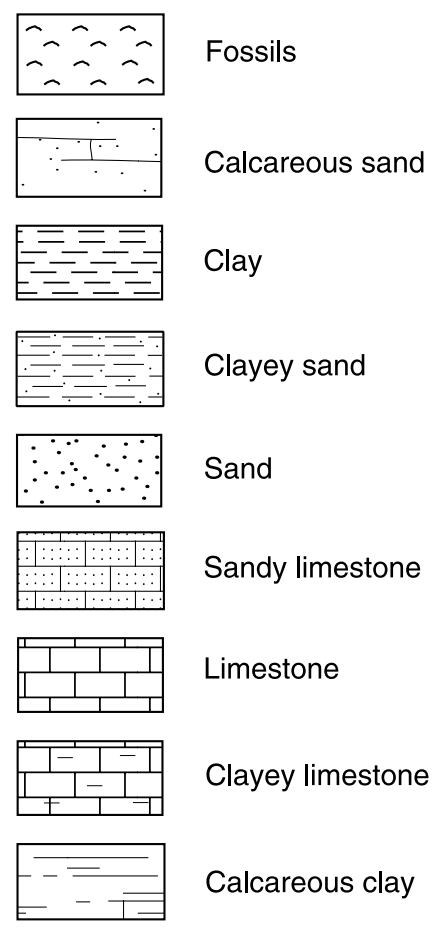

- Calcareous nannofossil sample

? Uncertain age

Figure 2. Calcareous nannofossil biostratigraphic zonation of Cenozoic intervals in the Millhaven core from Georgia. Lithology and formations from Falls and Prowell (this volume, chap. A). 
Species

\begin{tabular}{|c|c|c|c|c|c|c|c|c|c|c|c|c|c|c|c|c|c|c|c|c|c|c|c|c|c|c|c|c|c|}
\hline & \multicolumn{14}{|c|}{ Ellenton Formation } & \multicolumn{5}{|c|}{ Congaree Fm. } & & & & arley & Hil & 1 For & rmati & & & \\
\hline & $\begin{array}{r}\text { Earl } \\
\text { Paleoc }\end{array}$ & & & & & & & Late $\mathrm{Pa}$ & aleoce & & & & & & & & & & & & Middl & Hle Ec & ocene & & & & & & \\
\hline $\begin{array}{l}\text { ठ๊̃ } \\
\text { 之े }\end{array}$ & $\begin{array}{ll}\vec{\nabla} & + \\
\stackrel{亏}{z} & \bar{z}\end{array}$ & 艺 & $\begin{array}{l}n \\
\hat{z}\end{array}$ & ñ & & ñ & & $\begin{array}{ll}n & n \\
\hat{z} & \hat{z}\end{array}$ & $\hat{n}$ & $\begin{array}{l}n \\
\tilde{z}\end{array}$ & ñ & 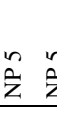 & & $\begin{array}{lll}\infty & \infty \\
\hat{z} & \hat{z} \\
\end{array}$ & & $\frac{ \pm}{z}$ & & & $\frac{\frac{n}{3}}{\frac{1}{z}}$ & & $\frac{n}{z}$ & $\frac{n}{z}$ & $\frac{n}{z}$ & & $\frac{n}{z}$ & $\frac{n}{z}$ & & & $\frac{o}{n}$ \\
\hline 节 $\Theta$ & 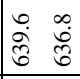 & 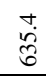 & $\frac{m}{3}$ & $\begin{array}{r}\stackrel{0}{0} \\
\text { ర్ర }\end{array}$ & 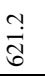 & $\vec{m}$ & $\begin{array}{l}\infty \\
\dot{0} \\
\dot{0}\end{array}$ & 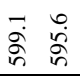 & ळ్ & $\begin{array}{l}\stackrel{\circ}{\circ} \\
\stackrel{\infty}{n} \\
\end{array}$ & $\begin{array}{l}\stackrel{\rho}{\dot{D}} \\
\stackrel{\infty}{\infty} \\
\stackrel{n}{n}\end{array}$ & & & $\begin{array}{l}\infty \\
\infty \\
i \\
i n\end{array}$ & 苟 & 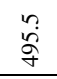 & $\begin{array}{c}n \\
\stackrel{\infty}{\infty} \\
+\infty\end{array}$ & 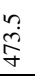 & $\begin{array}{l}n \\
n \\
b \\
+\end{array}$ & 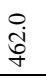 & $\begin{array}{l}\overrightarrow{0} \\
\dot{\infty} \\
\qquad \\
\end{array}$ & $\begin{array}{l}0 \\
\stackrel{0}{\circ} \\
\stackrel{5}{+}\end{array}$ & $\stackrel{m}{\tilde{f}}$ & $\begin{array}{l}n \\
\text { in } \\
\end{array}$ & 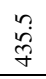 & 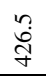 & 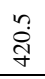 & & $\begin{array}{l}0 \\
\dot{+} \\
+\end{array}$ \\
\hline Blackites creber--- & & & & & & . & . & 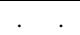 & . & & & & & & & & $\mathrm{x}$ & $\mathrm{x}$ & . & . & . & & & & . & & & & \\
\hline Blacki & & & & & . & . & . & . & . & & & & & & & & $\mathrm{x}$ & $\mathrm{x}$ & . & . & . & & & & . & . & . & $\mathrm{x}$ & \\
\hline Blackites spinosus - & . & & & & . & . & . & . & . & & & . & & . & & & . & . & . & . & . & & . & & . & . & . & . & \\
\hline Blackites tenuis --- & . & & & & . & . & . & . & . & & . & . & & . & & $\mathrm{x}$ & $\mathrm{x}$ & . & . & . & . & $\mathrm{x}$ & . & . & . & . & . & . & \\
\hline Braarudosphaera bigel & . & & & $\mathrm{x}$ & & $\mathrm{x}$ & . & . & $\mathrm{x}$ & & $\mathrm{x}$ & $\mathrm{x}$ & & $\mathrm{x}$ & $\mathrm{x}$ & $\mathrm{x}$ & $\mathrm{x}$ & $\mathrm{x}$ & $\mathrm{x}$ & $\mathrm{x}$ & $\mathrm{x}$ & $\mathrm{x}$ & $\mathrm{x}$ & $\mathrm{x}$ & $\mathrm{x}$ & $\mathrm{x}$ & $\mathrm{x}$ & $\mathrm{x}$ & $\mathrm{x}$ \\
\hline Braarudost & . & & & . & & . & . & . & & . & & & & . & $\cdot$ & . & & . & . & . & & . & . & & . & . & $\mathrm{x}$ & $\mathrm{x}$ & \\
\hline Braarudosphae & . & . & & . & . & . & . & . & . & . & . & & . & . & & . & . & . & . & . & $\mathrm{x}$ & . & . & . & . & . & . & & \\
\hline Campylosphaera dela------- & . & & & . & . & . & . & . & . & . & . & . & & . & & . & $\mathrm{x}$ & . & $\mathrm{x}$ & . & $\mathrm{x}$ & $\mathrm{x}$ & $\mathrm{x}$ & . & . & $\mathrm{x}$ & $\mathrm{x}$ & & $\mathrm{x}$ \\
\hline Cepekiella lumina ---- & . & & & . & . & . & . & . & . & . & . & . & . & . & & $\mathrm{x}$ & $\mathrm{x}$ & $\mathrm{x}$ & . & . & $\mathrm{x}$ & . & . & . & . & . & $\mathrm{x}$ & $\mathrm{x}$ & \\
\hline Chiasmolithus b & . & & $\mathrm{x}$ & $\mathrm{x}$ & $\mathrm{x}$ & $\mathrm{x}$ & . & $\mathrm{x}$ & $\mathrm{x}$ & & $\mathrm{x}$ & $\mathrm{x}$ & & $\mathrm{x} \quad \mathrm{x}$ & $\mathrm{x}$ & $\mathrm{x}$ & $\mathrm{x}$ & $\mathrm{x}$ & $\mathrm{x}$ & $\mathrm{x}$ & $\mathrm{x}$ & $\mathrm{x}$ & $\mathrm{x}$ & & . & . & . & & $\mathrm{x}$ \\
\hline Chiasmolithu & $\mathrm{x}$ & $\mathrm{x}$ & & . & . & . & . & . & . & . & . & . & & & & . & . & . & . & . & . & & . & . & . & . & . & . & \\
\hline Chiasmolithus consuetu & . & & & . & . & . & . & . & $\mathrm{x}$ & . & . & . & . & . & & . & . & . & . & . & . & . & . & . & . & . & . & . & \\
\hline Chiasmolithus eograndis ---.------ & . & & & . & . & . & . & . & . & . & . & . & . & . & 1 & . & . & . & . & . & . & . & . & . & . & . & . & . & \\
\hline Chiasmolithus expans & . & & & . & . & . & . & . & . & . & . & . & . & . & & . & . & . & . & . & . & $\mathrm{x}$ & . & . & . & . & . & . & \\
\hline Chiasmolithus gigas & . & & & . & . & . & . & . & . & . & . & . & . & . & 1 & . & . & . & . & . & $\mathrm{x}$ & . & $\mathrm{x}$ & . & . & . & $\mathrm{x}$ & $\mathrm{x}$ & \\
\hline Chias & . & & & . & . & . & & . & . & . & . & . & . & . & & . & $\mathrm{x}$ & . & & . & $\mathrm{x}$ & . & $\mathrm{x}$ & $\mathrm{x}$ & . & $\mathrm{x}$ & . & & $\mathrm{x}$ \\
\hline Chiasmolithus oamaruensis----. & . & & & . & . & . & . & . & . & . & . & . & . & . & & . & . & . & . & . & . & . & . & . & . & . & . & . & \\
\hline Chiasmolithus spp. small unsplit-- & . & & & . & . & . & . & . & . & . & . & . & . & . & $\mathrm{x}$ & . & $\mathrm{x}$ & $\mathrm{x}$ & $\mathrm{x}$ & . & $\mathrm{x}$ & $\mathrm{x}$ & $\mathrm{x}$ & $\mathrm{x}$ & $\mathrm{x}$ & $\mathrm{x}$ & $\mathrm{x}$ & $\mathrm{x}$ & $\mathrm{x}$ \\
\hline Chiphragmalithus a & . & & & . & . & . & . & . & . & . & . & . & . & . & & . & 2 & . & . & . & . & . & . & . & . & . & . & . & \\
\hline Coccolithu & $\mathrm{C}$ & . & & . & . & . & & . & . & . & . & . & . & . . & $\mathrm{x}$ & . & $\mathrm{x}$ & $\mathrm{x}$ & $\mathrm{x}$ & . & $\mathrm{x}$ & . & $\mathrm{x}$ & . & . & $\mathrm{x}$ & $\mathrm{x}$ & $\mathrm{x}$ & $\mathrm{x}$ \\
\hline Coccolithu & $\mathrm{x}$ & $\mathrm{x}$ & $\mathrm{x}$ & $\mathrm{x}$ & $\mathrm{x}$ & $\mathrm{x}$ & . & $\mathrm{x}$ & $\mathrm{x}$ & . & $\mathrm{x}$ & . & $\mathrm{x}$ & $\mathrm{x} \quad \mathrm{x}$ & $\mathrm{x}$ & $\mathrm{x}$ & $\mathrm{x}$ & $\mathrm{x}$ & $\mathrm{x}$ & $\mathrm{x}$ & $\mathrm{x}$ & $\mathrm{x}$ & $\mathrm{x}$ & $\mathrm{x}$ & $\mathrm{x}$ & $\mathrm{x}$ & $\mathrm{x}$ & $\mathrm{x}$ & $\mathrm{x}$ \\
\hline Cribrocentrum reticulatum--- & $\mathrm{C}$ & & & . & . & . & . & . & . & . & . & . & . & . & $\mathrm{C}$ & . & . & . & & . & . & . & . & . & . & . & . & . & \\
\hline Cruciolithus spp. --- & . & & & & . & . & . & . & . & . & . & . & . & . & & $\mathrm{x}$ & . & . & & . & . & . & . & . & . & . & . & . & \\
\hline Cruciplacolithus primus --- & $\mathrm{x}$ & & & & . & . & . & . & . & & . & . & . & . & & . & . & . & . & . & . & & . & . & . & . & . & . & \\
\hline Cruciplacolithus & . & . & & & . & . & . & . & . & . & . & . & . & . & & . & $\mathrm{x}$ & . & . & . & . & & . & . & . & . & . & . & \\
\hline Crucip & . & $\mathrm{x}$ & $\mathrm{x}$ & $\mathrm{x}$ & . & . & . & . & . & . & . & . & . & . & & . & . & . & . & . & . & . & . & . & . & . & . & . & \\
\hline Cruciplacolithus sp & . & & . & . & . & . & . & . & $\mathrm{x}$ & . & . & . & $\mathrm{x}$ & $\mathrm{x}$ & & $\mathrm{x}$ & . & $\mathrm{x}$ & . & . & . & . & . & . & . & . & . & . & \\
\hline Cyclagelosphaera pr & $\mathrm{x}$ & & $\mathrm{x}$ & . & . & . & . & . & . & . & . & & . & $\mathrm{x}$ & & . & . & . & . & . & . & . & . & . & . & . & . & . & \\
\hline Cyclococcolithus formosus ---- & . & & . & . & . & . & . & . & . & . & . & . & . & . & $\mathrm{x}$ & $\mathrm{x}$ & $\mathrm{x}$ & $\mathrm{x}$ & $\mathrm{x}$ & $\mathrm{x}$ & $\mathrm{x}$ & $\mathrm{x}$ & $\mathrm{x}$ & $\mathrm{x}$ & $\mathrm{x}$ & $\mathrm{x}$ & $\mathrm{x}$ & $\mathrm{x}$ & $\mathrm{x}$ \\
\hline Cyclococcolithus proto & . & & & & . & . & . & . & . & . & . & . & . & . & & . & $\mathrm{x}$ & . & . & . & . & & $\mathrm{x}$ & & . & . & . & . & \\
\hline Cyclococcolithus & . & & & & . & . & . & . & . & & . & & $\mathrm{x}$ & . & & . & $\mathrm{x}$ & . & . & . & $\mathrm{x}$ & & . & . & . & . & $\mathrm{x}$ & $\mathrm{x}$ & $\mathrm{x}$ \\
\hline Dictyococ & . & & & & . & . & . & . & . & & . & . & . & . & & . & . & . & . & . & . & & . & . & . & . & . & . & \\
\hline Dictyoce & . & & & & . & . & . & . & . & & . & & & . & & . & . & . & . & . & . & & . & . & . & . & . & . & \\
\hline Disco & . & . & & . & . & . & . & . & . & . & . & . & . & . & $\mathrm{x}$ & . & $\mathrm{x}$ & $\mathrm{x}$ & $\mathrm{x}$ & . & $\mathrm{x}$ & $\mathrm{x}$ & . & . & $\mathrm{x}$ & $\mathrm{x}$ & $\mathrm{x}$ & $\mathrm{x}$ & $\mathrm{x}$ \\
\hline Discoaster distinctus/deflandrei---. & . & & & . & & . & . & . & . & . & . & . & . & . & & . & $\mathrm{x}$ & . & . & . & 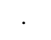 & . & $\mathrm{x}$ & . & . & . & . & & \\
\hline Discoaster kuepperi--------- & . & & & . & & . & . & . & . & . & . & & . & . & & $\mathrm{x}$ & & . & . & . & . & . & . & & . & . & . & & \\
\hline Discoaster sp. aff. D. kuepper & . & & & & . & . & . & . & . & . & . & . & . & . & & . & . & . & $\mathrm{x}$ & . & . & $\mathrm{x}$ & $\mathrm{x}$ & . & . & . & . & . & \\
\hline & . & & & & . & . & . & . & . & & . & . & & . & 1 & & . & . & . & . & . & & . & . & . & . & . & . & \\
\hline Discoaster lodoensi & . & & & & . & . & . & . & . & . & . & . & . & . & 3 & 1 & 1 & . & . & . & 1 & & . & . & . & . & . & . & \\
\hline Discoaster mirus - & . & & & & . & . & . & . & . & . & . & . & . & . & $\mathrm{x}$ & . & . & . & . & . & . & & . & . & . & . & . & . & \\
\hline Discoaster saipanensis - & . & & & . & & . & . & . & . & . & . & . & . & . & & . & $\mathrm{x}$ & $\mathrm{x}$ & . & . & $\mathrm{x}$ & . & $\mathrm{x}$ & & & . & . & $\mathrm{x}$ & \\
\hline Discoaster sublodoensis -- & . & & & & & . & . & . & . & . & . & & . & . & 3 & $\mathrm{x}$ & $\mathrm{x}$ & . & . & . & . & . & . & . & . & . & . & & \\
\hline & . & & & . & . & . & . & . & . & . & . & . & . & . & $\mathrm{x}$ & . & . & . & . & . & . & . & . & . & . & . & . & . & \\
\hline Discoaster & . & . & & . & . & . & . & . & . & . & . & . & . & . & & . & . & . & . & . & . & . & . & . & . & . & . & . & \\
\hline Ellipsolithus distichus & . & & & & . & . & . & . & . & & $\mathrm{x}$ & 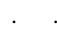 & . & . & $\mathrm{x}$ & & . & . & . & . & . & & . & & . & . & . & . & \\
\hline Ellipsolithus lajollaensis & . & & & & . & . & . & . & . & & . & & & . & & . & $\mathrm{x}$ & . & . & . & . & & . & & . & . & . & & \\
\hline Ellipsolith & $\mathrm{x}$ & & & & . & . & . & . & $\mathrm{x}$ & & $\mathrm{x}$ & & & & & . & . & . & . & . & . & & . & & . & . & . & & \\
\hline & . & . & & . & . & . & . & . & . & . & . & . & . & . & & . & . & . & . & . & $\mathrm{x}$ & . & . & . & . & . & . & . & \\
\hline Er & $\mathrm{x}$ & & $\mathrm{x}$ & $\mathrm{x}$ & $\mathrm{x}$ & $\mathrm{x}$ & . & . & $\mathrm{x}$ & & $\mathrm{x}$ & $\mathrm{x}$ & $\mathrm{x}$ & & & $\mathrm{x}$ & . & . & . & . & . & . & . & . & . & . & . & & \\
\hline Fasciculithus tympaniformis & . & & & . & . & . & . & . & . & . & $\mathrm{x}$ & . & . & & & . & . & . & . & . & . & . & . & & . & . & . & & \\
\hline Fasciculithus spp. ----- & . & & & . & . & . & . & . & . & . & . & & $\mathrm{x}$ & . & & . & . & . & . & . & . & . & . & & . & . & . & & \\
\hline olithus fluckigeri----- & & $\mathrm{x}$ & & & . & . & . & . & . & & . & . & . & & & . & . & . & & . & . & . & . & & & . & . & & \\
\hline & . & & & & . & . & . & . & . & & . & . & & & & . & . & . & . & & . & . & . & & . & . & . & & \\
\hline Helicosphaera bramlettei - & . & & & & . & . & . & & . & & & & . & & & . & . & . & 1 & & . & & . & & . & . & . & & \\
\hline Helicosphaera compacta -- & . & & & & . & . & . & . & . & 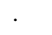 & 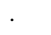 & . & . & . & & . & . & . & & . & . & . & . & & . & & . & & \\
\hline Helicosphaera intermedia- & . & & & & . & . & . & . & . & & & & & & & . & . & . & . & & . & . & . & & . & & . & & \\
\hline & . & & & & & . & & . & . & & . & . & & & & $\mathrm{x}$ & $\mathrm{x}$ & $\mathrm{x}$ & & & $\mathrm{x}$ & $\mathrm{x}$ & . & & . & . & . & $\mathrm{x}$ & \\
\hline Helicosphaera reticulata ----------- & & & & & & & & & . & & & & & & & & & & & & & & & & & & & & \\
\hline
\end{tabular}

Figure 3. Calcareous nannofossil occurrence chart for Cenozoic deposits in the Millhaven core from Georgia. The following symbols are used. Abundance: A, abundant or greater than 10 specimens per field of view at $\times 500$; C, common or 1 to 10 specimens per field of view at $\times 500$; F, frequent or 1 specimen per 1 to 10 fields of view at $\times 500$; $\mathrm{R}$, rare or 1 specimen in greater than 10 fields of view at $\times 500$; $\mathrm{B}$, barren of calcareous nannofossils. Preservation: F, fair; P, poor; T, terrible. Other symbols: $1,2,3$, only one, two, or three specimens observed in entire sample; C, contaminated specimen from elsewhere; ?, possible occurrence. 


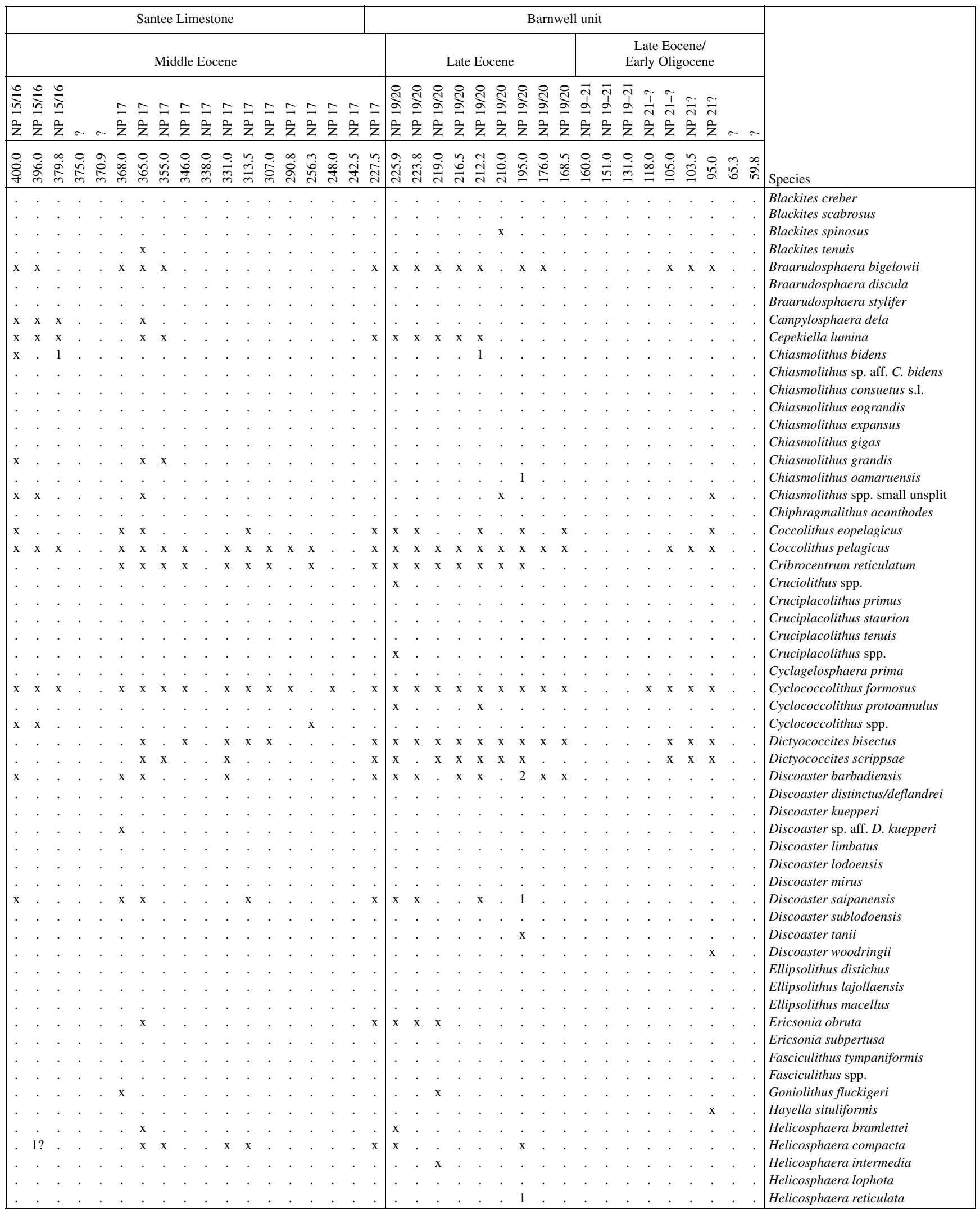

Figure 3. Continued. 


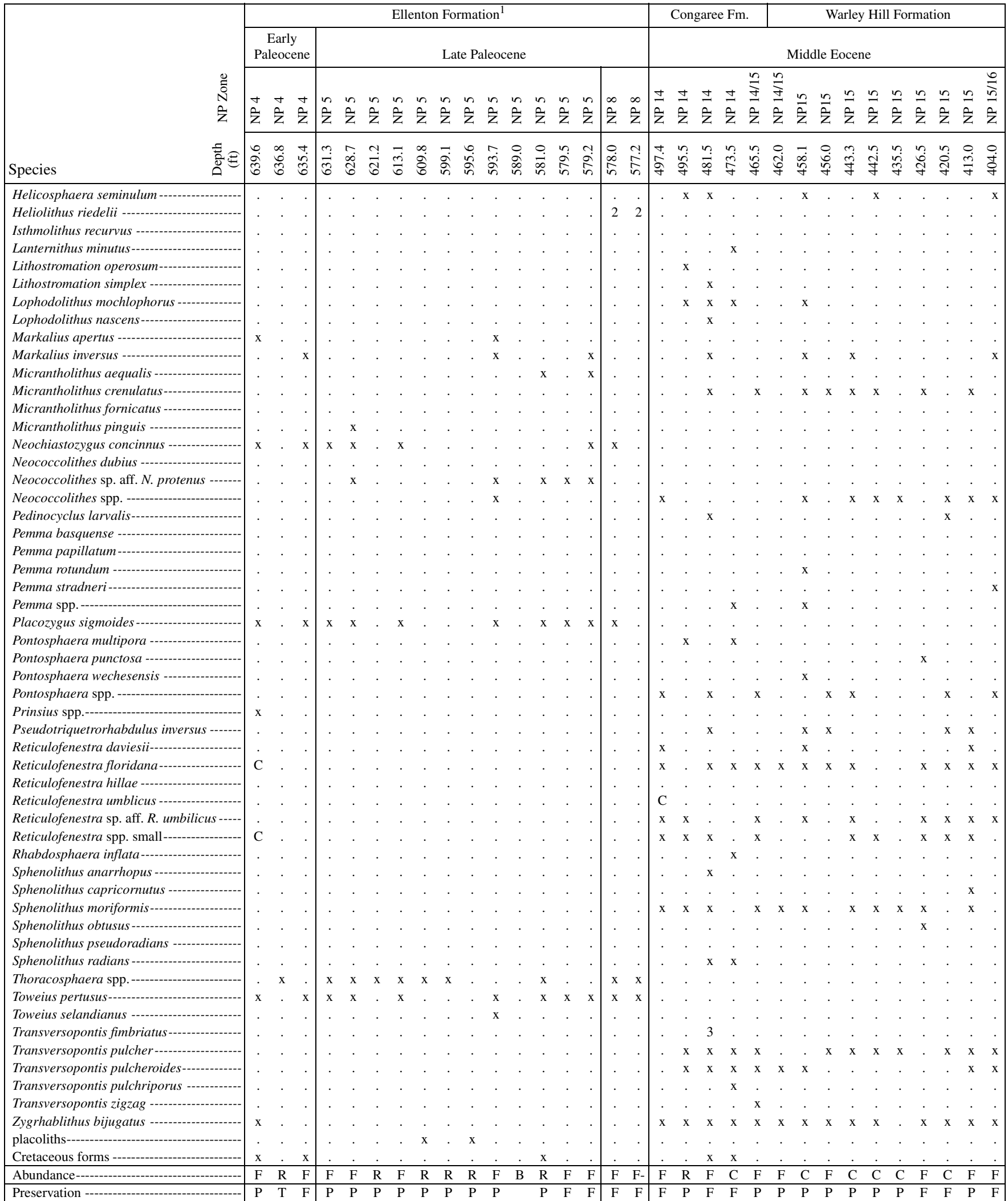

${ }^{1}$ The Snapp Formation was cored above the Ellenton Formation from 504 to $570 \mathrm{ft}$; the Snapp did not yield any calcareous nannofossil samples.

Figure 3. Calcareous nannofossil occurrence chart for Cenozoic deposits in the Millhaven core from Georgia. The following symbols are used. Abundance: A, abundant or greater than 10 specimens per field of view at $\times 500$; C, common or 1 to 10 specimens per field of view at $\times 500$; F, frequent or 1 specimen per 1 to 10 fields of view at $\times 500$; R, rare or 1 specimen in greater than 10 fields of view at $\times 500$; $\mathrm{B}$, barren of calcareous nannofossils. Preservation: F, fair; P, poor; T, terrible. Other symbols: $1,2,3$, only one, two, or three specimens observed in entire sample; $\mathrm{C}$, contaminated specimen from elsewhere; ?, possible occurrenceContinued. 


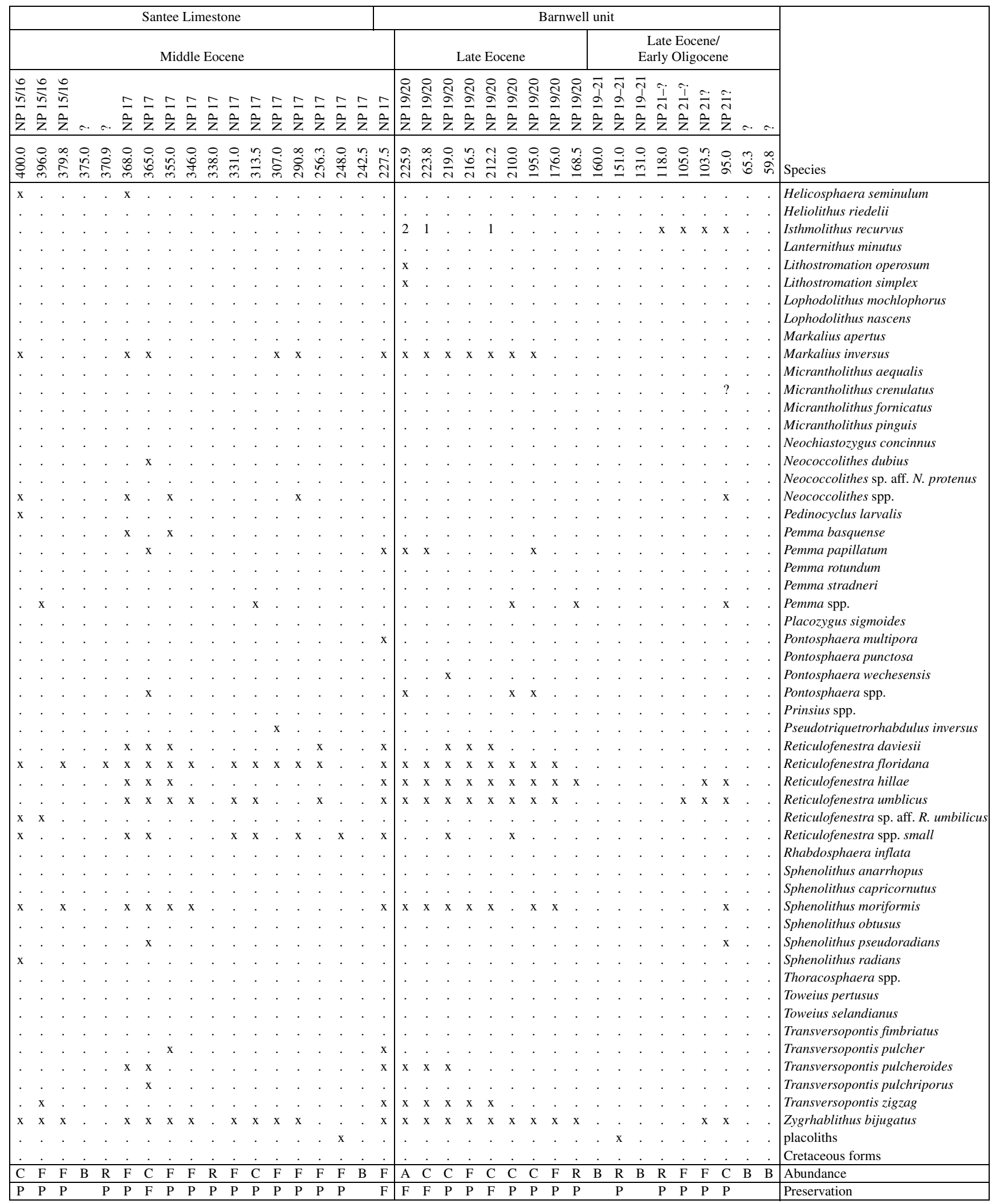

Figure 3. Continued. 
The following calcareous nannofossil species can be used to date sediments of early Paleocene to early Oligocene age. Many, but not all, of these species are present in the Millhaven core. A FAD indicates a first appearance datum, and a LAD indicates a last appearance datum. Zonal markers for the Martini NP zones are indicated with an asterisk (*), and a pound sign (\#) indicates a zonal marker for the Bukry CP zones. The author has found the remaining species to be biostratigraphically useful in the Gulf of Mexico and Atlantic Coastal Plains (Bybell, 1982; Bybell and Gibson, 1985; Poore and Bybell, 1988; Self-Trail and Bybell, 1995).

LAD *\#Reticulofenestra umbilicus (Levin) Martini \& Ritzkowski-top of Zone NP 22, top of Subzone CP 16c, early Oligocene

LAD *Cyclococcolithus formosus Kamptner-top of Zone NP 21, early Oligocene

LAD Isthmolithus recurvus Deflandre-within Zone NP 21

LAD *\#Discoaster saipanensis Bramlette \& Riedeltop of Zone NP 19/20, top of Subzone CP $15 \mathrm{~b}$, late Eocene

LAD \#Discoaster barbadiensis Tan Sin Hok-top of Zone NP 19/20, top of Subzone CP 15b, late Eocene; actually has its LAD slightly below the LAD of D. saipanensis

LAD Cribrocentrum reticulatum (Gartner \& Smith) Perch-Nielsen-very near top of Zone NP 19/20, late Eocene

FAD *Isthmolithus recurvus Deflandre-base of Zone NP 19/20, late Eocene

FAD *\#Chiasmolithus oamaruensis (Deflandre) Hay et al.- base of Zone NP 18, base of Subzone CP 15a, late Eocene

FAD Helicosphaera compacta Bramlette \& Wilcoxonwithin the uppermost part of Zone NP 16; can be used to approximate the Zone NP 16/ 17 boundary.

LAD *\#Chiasmolithus bidens (Bramlette \& Sullivan) Hay \& Mohler/Chiasmolithus solitus (Bramlette \& Sullivan) Hay et al.- top of Zone NP 16 , middle Eocene

FAD Cribrocentrum reticulatum (Gartner \& Smith) Perch-Nielsen-within Zone NP 16, middle Eocene

FAD Dictyococcites bisectus (Hay et al.) Bukry \& Percival—within Zone NP 16, middle Eocene

FAD Dictyococcites scrippsae Bukry \& Percivalwithin Zone NP 16, middle Eocene

FAD \#Reticulofenestra umbilicus (Levin) Martini \& Ritzkowski-large forms first appear near base of Zone NP 16, base of Subzone CP 14a, middle Eocene

LAD *Rhabdosphaera gladius Locker-top of Zone NP 15, middle Eocene
FAD *\#Nannotetrina fulgens (Stradner) Achuthan \& Stradner-base of Zone NP 15, base of Subzone CP 13a, middle Eocene, the genus Nannotetrina first appears very near the Zone NP $14 / 15$ boundary

LAD \#Rhabdosphaera inflata Bramlette \& Sullivantop of Zone NP 14, base of Subzone CP 12b, middle Eocene

FAD \#Rhabdosphaera inflata Bramlette \& Sullivanmiddle of Zone NP 14, top of Subzone CP $12 \mathrm{~b}$, middle Eocene

FAD *\#Discoaster sublodoensis Bramlette \& Sullivanbase of Zone NP 14, base of Subzone CP 12a, early Eocene

LAD *Rhomboaster orthostylus (Shamrai) Bybell \& Self-Trail-top of Zone NP 12, early Eocene

FAD Helicosphaera lophota (Bramlette \& Sullivan) Locker-near top of Zone NP 12; has been used to approximate the Zone NP 12/NP 13 boundary, early Eocene

FAD Helicosphaera seminulum Bramlette \& Sullivanmiddle of Zone NP 12, early Eocene

FAD *Discoaster lodoensis Bramlette \& Riedel-base of Zone NP 12, early Eocene

LAD *\#Rhomboaster contortus (Stradner) Bybell \& Self-Trail-top of Zone NP 10, top of Subzone CP 9a, early Eocene

FAD *Rhomboaster bramlettei (Brönnimann \& Stradner) Bybell \& Self-Trail-base of Zone NP 10, early Eocene

FAD

*\#Discoaster multiradiatus Bramlette \& Riedelbase of Zone NP 9, base of Subzone CP 8a, late Paleocene

FAD *Heliolithus riedelii Bramlette \& Sullivan-base of Zone NP 8, late Paleocene

FAD *\#Discoaster mohleri Bukry \& Percival-base of Zone NP 7, base of Zone CP 6, late Paleocene

FAD *\#Heliolithus kleinpellii Sullivan-base of Zone NP 6, base of Zone CP 5, late Paleocene

FAD Heliolithus cantabriae Perch-Nielsen-within upper part of Zone NP 5, late Paleocene

FAD Chiasmolithus bidens (Bramlette \& Sullivan) Hay \& Mohler-within Zone NP 5, late Paleocene

FAD *\#Fasciculithus tympaniformis Hay \& Mohlerbase of Zone NP 5, base of Zone CP 4, late Paleocene

FAD Chiasmolithus sp. aff. C. bidens (Bramlette \& Sullivan) Hay \& Mohler-within Zone NP 4

FAD Toweius pertusus (Sullivan) Romein-within Zone NP 4

FAD Ellipsolithus distichus (Bramlette \& Sullivan) Sullivan-near base of Zone NP 4, early Paleocene 
FAD

*\#Ellipsolithus macellus (Bramlette \& Sullivan) Sullivan-base of Zone NP 4, base of Zone CP 3, early Paleocene

FAD

*\#Chiasmolithus danicus (Brotzen) Hay \& Mohler-base of Zone NP 3, base of Zone CP 2, early Paleocene

FAD

*\#Cruciplacolithus tenuis (Stradner) Hay \& Mohler-base of Zone NP 2, base of Subzone CP 1b, early Paleocene

Calcareous nannofossil contamination normally is confined to occasional reworked specimens of Cretaceous species. However, at $639.6 \mathrm{ft}$ in the Millhaven core, there is a significant amount of downhole contamination of middle Eocene calcareous nannofossil specimens into a highly porous middle Paleocene sample. This is presumed to be the result of injection into open spaces of material from farther up in the corehole via drilling fluid. Contamination of Eocene pollen also was observed in this interval (see Frederiksen, this volume, chap. $\mathrm{H}$ ). Two samples in the Pregnall core in Dorchester County, S.C., also are contaminated with middle Eocene calcareous nannofossils (Edwards and others, 1997), but there the contamination occurs in porous upper Paleocene limestone rather than in the middle Paleocene section. The possibility for this type of contamination is always present when dealing with cores, but careful sampling procedures and awareness that contamination is possible can reduce significantly the chances for biostratigraphic dating errors.

\section{MILLHAVEN CORE}

\section{ELLENTON FORMATION, LOWER AND UPPER PALEOCENE, ZONES NP 4, NP 5, AND NP 8}

Sediments in the interval from 642 to $570 \mathrm{ft}$ in the Millhaven core are placed in the Ellenton Formation (Falls and Prowell, this volume, chap. A). Seventeen samples from 639.6 to $577.2 \mathrm{ft}$ in this unit were examined for their calcareous nannofossil content (fig. 3).

Three samples from 639.6, 636.8, and $635.4 \mathrm{ft}$ are placed in Zone NP 4 because of the presence of Ellipsolithus macellus (Bramlette \& Sullivan) Sullivan (FAD defines the base of Zone NP 4) and Chiasmolithus sp. aff. $C$. bidens (Bramlette \& Sullivan) Hay \& Mohler, which occurs only within Zone NP 4, and the absence of species indicative of Zone NP 5. The central X-shaped structure of $C$. sp. aff. C. bidens closely resembles that of Chiasmolithus bidens (Bramlette \& Sullivan) Sullivan, except that the $\mathrm{X}$ is unsplit. Perch-Nielsen (1985) contains a discussion of split versus unsplit terminology for the genus Chiasmolithus. Lower Zone NP 4 is placed in the early Paleocene, and upper Zone NP 4 is placed in the late Paleocene (Berggren and others, 1985, 1995). Calcareous nannofossils cannot be used to determine whether the samples from the Millhaven core are in the lower or upper part of Zone NP 4. However, dinoflagellates (Edwards, this volume, chap. G) and foraminifers (Gibson, this volume, chap. I) clearly place this interval within the early Paleocene. For example, the planktonic foraminifer Globoconusa daubjergensis (Brönnimann), which occurs at $636.8 \mathrm{ft}$, never occurs in material younger than the lower Paleocene (Gibson, this volume, chap. I).

The 12 samples from 631.3 to $579.2 \mathrm{ft}$ are placed within the lower part of Zone NP 5 (late Paleocene) by the presence of Chiasmolithus bidens (Bramlette \& Sullivan) Hay \& Mohler (FAD within Zone NP 5) and the absence of both Heliolithus cantabriae Perch-Nielsen (FAD in upper half of Zone NP 5) and Heliolithus kleinpellii Sullivan (FAD defines the base of Zone NP 6). Fasciculithus tympaniformis Hay \& Mohler (FAD defines the base of Zone NP 5) is rare in the Millhaven core and could not be used as a reliable biostratigraphic indicator. An unconformity within the Ellenton Formation comprises the upper part of Zone NP 4.

Two samples from 578.0 and $577.2 \mathrm{ft}$ are placed in the late Paleocene Zone NP 8 on the basis of the presence of Heliolithus riedelii Bramlette \& Sullivan (FAD defines the base of Zone NP 8) and the absence of Discoaster multiradiatus Bramlette \& Riedel (FAD defines the base of Zone NP 9). An unconformity in the Ellenton spans the upper part of Zone 5 and Zones NP 6-7. No calcareous nannofossil samples were collected from the upper $7 \mathrm{ft}$ of the Ellenton Formation. It is unknown whether there might be material of Zone NP 9 age (uppermost Paleocene) in this interval. Zone NP 9 is present in Dorchester County, S.C., both in the Pregnall core (Edwards and others, 1997) and in the Clubhouse Crossroads No. 1 core (Hazel and others, 1977).

\section{SNAPP FORMATION}

Calcareous nannofossils were not examined from the noncalcareous Snapp Formation, which extends between 570 and $504 \mathrm{ft}$ in the core. See Frederiksen (this volume, chap. H) for a discussion of the pollen from the Snapp Formation.

\section{CONGAREE FORMATION, MIDDLE EOCENE, ZONE NP 14 AND POSSIBLY ZONE NP 15}

Five samples were examined from the Congaree Formation, which extends from 504 to $462 \mathrm{ft}$ in the Millhaven core (fig. 3). Four samples from 497.4, 495.5, 481.5, and $473.5 \mathrm{ft}$ can be placed in Zone NP 14 by the presence of Discoaster sublodoensis Bramlette \& Sullivan (FAD defines the base of Zone NP 14) at 497.4, 495.5, and $481.5 \mathrm{ft}$; the presence of Rhabdosphaera inflata Bramlette \& Sullivan 
(only occurs in the upper part of Zone NP 14) at $473.5 \mathrm{ft}$; and the absence of the genus Nannotetrina (FAD at the base of Zone NP 15) in this material. Discoaster saipanensis Bramlette \& Riedel (early forms of this species first appear in Zone NP 14), Lanternithus minutus Stradner (first appears in the upper part of Zone NP 14), and Lithostromation operosum (Deflandre) Bybell and Lithostromation simplex (Klumpp) Bybell (both first appear in Zone NP 14) are present in this interval. The sample at $473.5 \mathrm{ft}$, which is definitely in the upper part of Zone NP 14 because of the presence of Rhabdosphaera inflata Bramlette \& Sullivan, is middle Eocene in age. The absence of $R$. inflata Bramlette $\&$ Sullivan in the lower three samples could indicate that these samples are from the lower part of Zone NP 14 (upper part of the early Eocene) or, more probably, the absence is the result of poor calcareous nannofossil assemblages in these samples. The sample from $465.5 \mathrm{ft}$ contains no diagnostic species and could be in either Zone NP 14 or Zone NP 15.

\section{WARLEY HILL FORMATION, MIDDLE EOCENE, ZONE NP 15 AND POSSIBLY ZONE NP 16}

Ten samples were examined from the Warley Hill Formation, which extends from 462 to $401 \mathrm{ft}$ in the Millhaven core (fig. 3). The lowest sample from $462.0 \mathrm{ft}$ can be dated no closer than either Zone NP 14 or Zone NP 15. Eight samples from 458.1 to $413.0 \mathrm{ft}$ are placed in Zone NP 15 because of the presence of Chiasmolithus gigas (Bramlette \& Sullivan) Hay et al. (FAD and LAD in Zone NP 15) in this interval and because large specimens of Reticulofenestra umbilicus (Levin) Martini \& Ritzkowski (FAD near the base of Zone NP 16) are not present. The sample from 404.0 $\mathrm{ft}$ can be no older than Zone NP 15 because it overlies sediments of this age and can be no younger than Zone NP 16 because it contains Chiasmolithus bidens (Bramlette \& Sullivan) Hay \& Mohler/Chiasmolithus solitus (Bramlette \& Sullivan) Hay et al. (LAD defines the top of Zone NP 16).

\section{SANTEE LIMESTONE, MIDDLE EOCENE, ZONE NP 17 AND POSSIBLY ZONES NP 15 OR NP 16}

Seventeen samples were examined from the Santee Limestone, which extends from 401 to $228 \mathrm{ft}$ in the Millhaven core (fig. 3). The deepest three samples from 400.0 to $379.8 \mathrm{ft}$ tentatively are placed in Zones NP 15 or NP 16 because they contain Chiasmolithus bidens (Bramlette \& Sullivan) Hay \& Mohler/Chiasmolithus solitus (Bramlette \& Sullivan) Hay et al. (LAD defines the top of Zone NP 16) and overlie samples of Zone NP 15 age. The sample from $375.0 \mathrm{ft}$ is barren of calcareous nannofossils, and the sample from $370.9 \mathrm{ft}$ contains only rare nondiagnostic species.
At $368.0 \mathrm{ft}$, the sample does contain frequent calcareous nannofossils and a moderate assemblage with 21 species present. The absence of Chiasmolithus bidens (Bramlette \& Sullivan) Hay \& Mohler/Chiasmolithus solitus (Bramlette \& Sullivan) Hay et al. is considered to be significant, and this sample is placed in Zone NP 17. The 11 samples in the interval from 365.0 to $242.5 \mathrm{ft}$ also are placed in Zone NP 17 because of the absence of Chiasmolithus bidens (Bramlette \& Sullivan) Hay \& Mohler/Chiasmolithus solitus (Bramlette \& Sullivan) Hay et al. (LAD at the top of Zone NP 16) and the presence of Helicosphaera compacta Bramlette \& Wilcoxon (FAD very near the top of Zone NP 16), Reticulofenestra umbilicus (Levin) Martini \& Ritzkowski, Cribrocentrum reticulatum (Gartner \& Smith) Perch-Nielsen, Dictyococcites bisectus (Hay et al.) Bukry \& Percival, and Dictyococcites scrippsae Bukry \& Percival (FAD's in Zone NP 16).

\section{BARNWELL UNIT, UPPER EOCENE AND POSSIBLY LOWER OLIGOCENE, ZONES NP 19/20-21}

Nineteen samples were examined from the Barnwell unit between 227.5 and $59.8 \mathrm{ft}$ in the Millhaven test hole. The lowest calcareous nannofossil sample from the Barnwell unit at $227.5 \mathrm{ft}$ tentatively has been placed in the middle Eocene Zone NP 17 because it overlies material of Zone NP 17 age but contains no species indicative of a younger age. The fact that the rest of the Barnwell unit is in the late Eocene (Zone NP 19/20 or younger) indicates that this sample most likely is also of late Eocene age, and the age discrepancy is the result of the absence of diagnostic late Eocene species in the sample. The author has observed similar discrepancies near formational contacts elsewhere in the Gulf of Mexico and Atlantic Coastal Plains.

The nine samples that were examined from 225.9 to $168.5 \mathrm{ft}$ are placed in Zone NP 19/20 because of the presence of Isthmolithus recurvus Deflandre (FAD defines the base of Zone NP 19/20), Discoaster saipanensis Bramlette \& Riedel (LAD defines the top of Zone NP 19/20), Discoaster barbadiensis Tan Sin Hok, and Cribrocentrum reticulatum (Gartner \& Smith) Perch-Nielsen (LAD's very near the top of Zone NP 19/20). The three samples from 160.0, 151.0 , and $131.0 \mathrm{ft}$ can be dated no more accurately than Zone NP 19/20 or Zone NP 21. This is because the samples from 160.0 and $131.0 \mathrm{ft}$ are barren of calcareous nannofossils and the sample at $151.0 \mathrm{ft}$ contains only rare and poorly preserved specimens.

Four samples at 118.0, 105.0, 103.5, and $95.0 \mathrm{ft}$ questionably are placed in Zone NP 21. All four samples contain Isthmolithus recurvus Deflandre (FAD at the base of Zone NP 19/20 and LAD in Zone NP 21) and Cyclococcolithus formosus Kamptner (LAD defines the top of Zone NP 21). Also, all four samples do not have Discoaster barbadiensis 
Tan Sin Hok, Discoaster saipanensis Bramlette \& Riedel, or Cribrocentrum reticulatum (Gartner \& Smith) PerchNielsen (LAD's near or at the top of Zone NP 20). However, the absence of all but one specimen of the genus Discoaster in this interval could possibly indicate that Discoaster barbadiensis Tan Sin Hok and Discoaster saipanensis Bramlette \& Riedel are absent for other than evolutionary reasons. There is a possibility that this material is still in Zone NP 19/20. The Eocene/Oligocene boundary occurs within Zone NP 21 (Berggren and others, 1985, 1995). So if this interval in the Millhaven core is in Zone NP 21, it could be either late Eocene or early Oligocene in age.

The two samples from 65.3 and $59.8 \mathrm{ft}$ are barren of calcareous nannofossils. Two samples from 65.5 and $59.6 \mathrm{ft}$ were examined by Jonathan R. Bryan of Okaloosa-Walton Community College in Niceville, Fla., for their larger foraminifers, which indicate either a latest Eocene or an earliest Oligocene age, with the Oligocene being more likely.

\section{GIRARD CORE}

Two samples were examined from the Ellenton Formation in the Girard core (fig. 1) at 521.0 and $514.0 \mathrm{ft}$. Both samples were barren of calcareous nannofossils.

\section{MILLERS POND CORE}

Three samples were examined from the Santee Limestone in the Millers Pond core (fig. 1). Species from the lowest sample at $148 \mathrm{ft}$, which contained rare calcareous nannofossils with poor preservation, are as follows:

Braarudosphaera bigelowii (Gran \& Braarud) Deflandre Helicosphaera lophota (Bramlette \& Sullivan) Locker Reticulofenestra sp.

Species from the middle sample at $120 \mathrm{ft}$, which contained frequent calcareous nannofossils with poor preservation, are as follows:

Campylosphaera dela (Bramlette \& Sullivan) Hay \& Mohler

Coccolithus pelagicus (Wallich) Schiller

Cyclococcolithus formosus Kamptner

Ericsonia obruta Perch-Nielsen

Neococcolithes sp.

Pemma papillatum Martini

Pontosphaera multipora (Kamptner) Roth

Reticulofenestra daviesii (Haq) Haq

Reticulofenestra floridana (Roth \& Hay) Theodoridis

Reticulofenestra umbilicus (Levin) Martini \& Ritzkowski

Rhabdosphaera sp.

Sphenolithus moriformis (Brönnimann \& Stradner) Bramlette \& Wilcoxon

Transversopontis pulcher (Deflandre) Perch-Nielsen
Transversopontis pulcheroides (Sullivan) Báldi-Beke

Transversopontis zigzag Roth \& Hay

Zygrhablithus bijugatus (Deflandre) Deflandre

The age of the sample at $120 \mathrm{ft}$ is middle to late Eocene, and unfortunately cannot be constrained any closer than Zones NP 16 to NP 21. The highest sample at $82 \mathrm{ft}$ was barren of calcareous nannofossils.

\section{LIST OF CALCAREOUS NANNOFOSSIL SPECIES MENTIONED IN THIS PAPER}

[Selected well-preserved specimens from the Millhaven core are shown in plate 1 as indicated below]

Blackites creber (Deflandre in Deflandre and Fert, 1954) Stradner \& Edwards 1968

Blackites scabrosus (Deflandre in Deflandre and Fert, 1954) Roth 1970 (this paper, pl. 1, fig. 8)

Blackites spinosus (Deflandre \& Fert 1954) Hay \& Towe 1962

Blackites tenuis (Bramlette \& Sullivan 1961) Sherwood 1974

Braarudosphaera bigelowii (Gran \& Braarud 1935) Deflandre 1947

Braarudosphaera discula Bramlette \& Riedel 1954

Braarudosphaera stylifer Troelsen \& Quadros 1971

Campylosphaera dela (Bramlette \& Sullivan 1961) Hay \& Mohler 1967

Cepekiella lumina (Sullivan 1965) Bybell 1975

Chiasmolithus bidens (Bramlette \& Sullivan 1961) Hay \& Mohler 1967

Chiasmolithus consuetus (Bramlette \& Sullivan 1961) Hay \& Mohler 1967

Chiasmolithus danicus (Brotzen 1959) Hay \& Mohler 1967

Chiasmolithus eograndis Perch-Nielsen 1971

Chiasmolithus expansus (Bramlette \& Sullivan 1961) Hay et al. 1966

Chiasmolithus gigas (Bramlette \& Sullivan 1961) Hay et al. 1966

Chiasmolithus grandis (Bramlette \& Riedel 1954) Hay et al. 1966

Chiasmolithus oamaruensis (Deflandre in Deflandre and Fert, 1954) Hay et al. 1966

Chiasmolithus solitus (Bramlette \& Sullivan 1961) Hay et al. 1966

Chiphragmalithus acanthodes Bramlette \& Sullivan 1961

Coccolithus eopelagicus (Bramlette \& Riedel 1954) Bramlette \& Sullivan 1961

Coccolithus pelagicus (Wallich 1877) Schiller 1930 (this paper, pl. 1, figs. 1, 11)

Cribrocentrum reticulatum (Gartner \& Smith 1967) Perch-Nielsen 1971

Cruciplacolithus primus Perch-Nielsen 1977 
Cruciplacolithus staurion (Bramlette \& Sullivan 1961) Gartner 1971

Cruciplacolithus tenuis (Stradner 1961) Hay \& Mohler in Hay and others (1967)

Cyclagelosphaera prima (Bukry 1969) Bybell \& Self-Trail 1995

Cyclococcolithus formosus Kamptner 1963

Cyclococcolithus protoannulus (Gartner 1971) Haq \& Lohmann 1976

Dictyococcites bisectus (Hay et al. 1966) Bukry \& Percival 1971

Dictyococcites scrippsae Bukry \& Percival 1971

Discoaster barbadiensis Tan Sin Hok 1927 (this paper, pl. 1, fig. 2)

Discoaster deflandrei Bramlette \& Riedel 1954 (this paper, pl. 1, fig. 6)

Discoaster distinctus Martini 1958

Discoaster kuepperi Stradner 1959

Discoaster limbatus Bramlette \& Sullivan 1961

Discoaster lodoensis Bramlette \& Riedel 1954

Discoaster mirus Deflandre in Deflandre and Fert (1954)

Discoaster mohleri Bukry \& Percival 1971

Discoaster multiradiatus Bramlette \& Riedel 1954

Discoaster saipanensis Bramlette \& Riedel 1954

Discoaster sublodoensis Bramlette \& Sullivan 1961 (this paper, pl. 1, fig. 3)

Discoaster tanii Bramlette \& Riedel 1954

Discoaster woodringii Bramlette \& Riedel 1954

Ellipsolithus distichus (Bramlette \& Sullivan 1961) Sullivan 1964

Ellipsolithus lajollaensis Bukry \& Percival 1971

Ellipsolithus macellus (Bramlette \& Sullivan 1961) Sullivan 1964

Ericsonia obruta Perch-Nielsen 1971

Ericsonia subpertusa Hay \& Mohler 1967 (this paper, pl. 1, fig. 10)

Fasciculithus tympaniformis Hay \& Mohler in Hay and others (1967)

Goniolithus fluckigeri Deflandre 1957

Hayella situliformis Gartner 1969

Helicosphaera bramlettei (Müller 1970) Jafar \& Martini 1975

Helicosphaera compacta Bramlette \& Wilcoxon 1967

Helicosphaera intermedia Martini 1965

Helicosphaera lophota (Bramlette \& Sullivan 1961) Locker 1973 (this paper, pl. 1, fig. 7)

Helicosphaera reticulata Bramlette \& Wilcoxon 1967

Helicosphaera seminulum Bramlette \& Sullivan 1961

Heliolithus cantabriae Perch-Nielsen 1971

Heliolithus kleinpellii Sullivan 1964

Heliolithus riedelii Bramlette \& Sullivan 1961

Isthmolithus recurvus Deflandre in Deflandre and Fert (1954)

Lanternithus minutus Stradner 1962
Lithostromation operosum (Deflandre in Deflandre and Fert, 1954) Bybell 1975

Lithostromation simplex (Klumpp 1953) Bybell 1975

Lophodolithus mochlophorus Deflandre in Deflandre and Fert (1954)

Lophodolithus nascens Bramlette \& Sullivan 1961

Markalius apertus Perch-Nielsen 1979

Markalius inversus (Deflandre in Deflandre and Fert, 1954) Bramlette \& Martini 1964

Micrantholithus aequalis Sullivan 1964

Micrantholithus crenulatus Bramlette \& Sullivan 1961

Micrantholithus fornicatus Martini 1961

Micrantholithus pinguis Bramlette \& Sullivan 1961

Nannotetrina fulgens (Stradner 1960) Achuthan \& Stradner 1969

Neochiastozygus concinnus (Martini 1961) Perch-Nielsen 1971

Neococcolithes dubius (Deflandre in Deflandre and Fert, 1954) Black 1967

Neococcolithes protenus (Bramlette \& Sullivan 1961) Black 1967

Pedinocyclus larvalis Bukry \& Bramlette 1971

Pemma basquense (Martini 1959) Bybell \& Gartner 1972

Pemma papillatum Martini 1959

Pemma rotundum Klumpp 1953

Pemma stradneri (Chang 1969) Perch-Nielsen 1971

Placozygus sigmoides (Deflandre in Deflandre and Fert, 1954) Black 1967 (this paper, pl. 1, fig. 9)

Pontosphaera multipora (Kamptner ex Deflandre 1959) Roth 1970

Pontosphaera punctosa (Bramlette \& Sullivan 1961) Perch-Nielsen 1984

Pontosphaera wechesensis (Bukry \& Percival 1971) Aubry 1986

Pseudotriquetrorhabdulus inversus (Bukry \& Bramlette 1969) Wise in Wise and Constans (1976)

Reticulofenestra daviesii (Haq 1968) Haq 1971

Reticulofenestra floridana (Roth \& Hay in Hay and others, 1967) Theodoridis 1984 (this paper, pl. 1, fig. 4)

Reticulofenestra hillae Bukry \& Percival 1971

Reticulofenestra umbilicus (Levin 1965) Martini \& Ritzkowski 1968

Rhabdosphaera gladius Locker 1967

Rhabdosphaera inflata Bramlette \& Sullivan 1961

Rhomboaster bramlettei (Brönnimann \& Stradner 1960) Bybell \& Self-Trail 1995

Rhomboaster contortus (Stradner 1958) Bybell \& Self-Trail 1995

Rhomboaster orthostylus (Shamrai 1963) Bybell \& Self-Trail 1995

Sphenolithus anarrhopus Bukry \& Bramlette 1969

Sphenolithus capricornutus Bukry \& Percival 1971

Sphenolithus moriformis (Brönnimann \& Stradner 1960) Bramlette \& Wilcoxon 1967

Sphenolithus obtusus Bukry 1971 
Sphenolithus pseudoradians Bramlette \& Wilcoxon 1967

Sphenolithus radians Deflandre in Grassé (1952)

Toweius pertusus (Sullivan 1965) Romein 1979

Toweius selandianus Perch-Nielsen 1979 (this paper, pl. 1, fig. 12)

Transversopontis fimbriatus (Bramlette \& Sullivan 1961) Locker 1968

Transversopontis pulcher (Deflandre in Deflandre and Fert, 1954) Perch-Nielsen 1967

Transversopontis pulcheroides (Sullivan 1964) Báldi-Beke 1971 (this paper, pl. 1, fig. 5)

Transversopontis pulchriporus (Reinhardt 1967) Sherwood 1974

Transversopontis zigzag Roth \& Hay in Hay and others, 1967

Zygrhablithus bijugatus (Deflandre in Deflandre and Fert, 1954) Deflandre 1959

\section{REFERENCES CITED}

Berggren, W.A., Kent, D.V., Flynn, J.J., and Van Couvering, J.A., 1985, Cenozoic geochronology: Geological Society of America Bulletin, v. 96, p. 1407-1418.

Berggren, W.A., Kent, D.V., Swisher, C.C., III, and Aubry, M.-P., 1995, A revised Cenozoic geochronology and chronostratigraphy, in Berggren, W.A., Kent, D.V., Aubry, M.-P., and Hardenbol, Jan, eds., Geochronology, time scales and global stratigraphic correlation: SEPM (Society for Sedimentary Geology) Special Publication 54, p. 129-212.

Bukry, David, 1973, Low-latitude coccolith biostratigraphic zonation, in Edgar, N.T., Saunders, J.B., Bolli, H.M., Boyce, R.E., Broecker, W.S., Donnelly, T.W., Gieskes, J.M., Hay, W.W., Horowitz, R.M., Maurrasse, Florentin, Perez Nieto, Hernan, Prell, Warren, Premoli Silva, Isabella, Riedel, W.R., Schneidermann, Nahum, Waterman, L.S., Kaneps, A.G. (ed.), Herring, J.R. (ed.), Initial reports of the Deep Sea Drilling Project, v. 15: Washington, D.C., U.S. Government Printing Office, p. 685-703.

1978, Biostratigraphy of Cenozoic marine sediments by calcareous nannofossils: Micropaleontology, v. 24, p. 44-60.

Bybell, L.M., 1982, Late Eocene to early Oligocene calcareous nannofossils in Alabama and Mississippi: Gulf Coast Association of Geological Societies Transactions, v. 32, p. 295-302.

Bybell, L.M., and Gibson, T.G., 1985, The Eocene Tallahatta Formation of Alabama and Georgia-Its lithostratigraphy, biostratigraphy, and bearing on the age of the Claibornian Stage: U.S. Geological Survey Bulletin 1615, 20 p.
Deflandre, Georges, and Fert, Charles, 1954, Observations sur les Coccolithophoridés actuels et fossiles en microscopie ordinaire et électronique: Annales de Paléontologie, v. 40, p. 115176.

Edwards, L.E., Bybell, L.M., Gohn, G.S., and Frederiksen, N.O., 1997, Paleontology and physical stratigraphy of the USGS Pregnall No. 1 core (DOR-208), Dorchester County, South Carolina: U.S. Geological Survey Open-File Report 97-145, $35 \mathrm{p}$.

Grassé, P.P., 1952, Traité de zoologie: Paris, Masson, 1071 p.

Hay, W.W., Mohler, H.P., Roth, P.H., Schmidt, R.R., and Boudreaux, J.E., 1967, Calcareous nannoplankton zonation of the Cenozoic of the Gulf Coast and Caribbean-Antillean area and transoceanic correlation: Gulf Coast Association of Geological Societies Transactions, v. 17, p. 428-480.

Hazel, J.E., Bybell, L.M., Christopher, R.A., Frederiksen, N.O., May, F.E., McLean, D.M., Poore, R.Z., Smith, C.C., Sohl, N.F., Valentine, P.C., and Witmer, R.J., 1977, Biostratigraphy of the deep corehole (Clubhouse Crossroads Corehole 1) near Charleston, South Carolina, chap. F of Rankin, D.W., ed., Studies related to the Charleston, South Carolina, earthquake of 1886-A preliminary report: U.S. Geological Survey Professional Paper 1028, p. 71-89.

Martini, Erlend, 1971, Standard Tertiary and Quaternary calcareous nannoplankton zonation: Planktonic Conference, 2d, Rome, 1969, Proceedings, p. 739-785.

Okada, Hisatake, and Bukry, David, 1980, Supplementary modification and introduction of code numbers to the low-latitude coccolith biostratigraphic zonation (Bukry, 1973; 1975): Marine Micropaleontology, v. 5, no. 3, p. 321-325.

Perch-Nielsen, Katharina, 1985, Cenozoic calcareous nannofossils, in Bolli, H.M., Saunders, J.B., and Perch-Nielsen, Katharina, eds., Plankton stratigraphy: New York, Cambridge University Press, p. 427-554.

Poore, R.Z., and Bybell, L.M., 1988, Eocene to Miocene biostratigraphy of New Jersey core ACGS \#4-Implications for regional stratigraphy: U.S. Geological Survey Bulletin 1829, 22 p., 8 fossil pls., 2 tables in pocket.

Self-Trail, J.M., and Bybell, L.M., 1995, Cretaceous and Paleogene calcareous nannofossil biostratigraphy of New Jersey, in Baker, J.E.B., ed., Contributions to the paleontology of New Jersey: Geological Association of New Jersey Contribution Proceedings, v. 12, p. 102-139.

Wise, S.W., Jr., and Constans, R.E., 1976, Mid Eocene planktonic correlations, northern Italy-Jamaica, W.I.: Gulf Coast Association of Geological Societies Transactions, v. 26, p. 144-155. 